\title{
Portuguese Cultural Studies/ Cultural Studies in Portugal: Some Thoughts on the Making and Remaking of a Field
}

\author{
By Sofia Sampaio
}

\begin{abstract}
This article discusses the overall situation of cultural studies in Portugal. It starts by analysing some of the courses and graduate programmes currently on offer. The results suggest that cultural studies is experiencing a fast academic expansion. While this seems to be entangled with top-down institutional changes, in the wake of the Bologna process and the turn to the cultural/ creative industries and as part of a more general shift to the 'new economy', there are reasons to believe that alternative understandings of cultural studies have not died out. The name 'cultural studies' continues to cause unease in some academic quarters (namely, in literary studies) and there is ambiguity regarding what is meant by it. Cautioning against the tendency to reduce Portuguese cultural studies to a straightforward import from the Anglophone world, I argue for the need to conduct historically informed research on local strands and traditions of cultural theory and critique. I conclude that only a combined synchronic and diachronic approach - one that is sensitive to national and transnational contexts and intersections - will allow us to gain a better understanding of the deep-running contradictions that characterise the field, helping us to clarify the stakes and reconnect to a socially relevant and critique-orientated intellectual project.
\end{abstract}

Keywords: Cultural studies, Portugal, Bologna, 'new economy’, cultural critique. 


\section{Introduction}

The story of the emergence, ascent and institutionalisation of cultural studies has been told several times in the English-speaking world, where cultural studies originally appeared (first around the figures of Richard Hoggart, E.P. Thompson and Raymond Williams and then under the formative influence of Stuart Hall and the Birmingham school) and where it has flourished over the past three decades. In Portugal, however, this story remains to be told. This applies whether we take Portuguese cultural studies to be largely derivative of an international, and hegemonic, Anglo-American cultural studies strand (which the direct translation into 'estudos culturais', no doubt, suggests) or understand it in a more nuanced way, as a specific approach to culture and its study that must be connected to earlier intellectual practices, forged locally, within and in relation to certain national institutions, notwithstanding their links with other international formations.

The article is divided into two: in the first section I report on the current state of cultural studies in Portuguese universities and research centres, especially by looking at the presence of cultural studies in university courses and graduate programmes. My findings confirm the general idea that cultural studies - or something that goes by that name - is experiencing a fast academic expansion. Many researchers can now relate to cultural studies ideas or practices, even if loosely, and some use it to describe their research interests. However, this expansion seems to be - perhaps atypically - more entangled with internal, top-down institutional changes (triggered or facilitated by the Bologna process, on the one hand, and a growing interest in the cultural industries, on the other) than with overtlywaged cultural, political and academic wars. Tensions do exist - the naming of 'cultural studies' continues to raise discomfort in some academic quarters (namely, in English and American studies) - but they appear to have been sidestepped by institutional reforms, which perhaps explains why cultural studies is having a relatively quiet success story within certain academic quarters, while remaining not quite accepted, in others.

In the second section, I problematise these findings, stressing the need to complement this analysis with an account of other, more localised, intellectual strands that have also flowed into the cultural studies project. Further research is needed to trace these hidden lineages and genealogies and unravel the ties between local and national projects and agendas, on the one hand, and international and transnational projects, on the other - in the guise of the 'radically contextualist work' that Lawrence Grossberg has identified cultural studies with (Grossberg 2010). The full grasp of the field's current tensions and contradictions, as well as the future of socially relevant and critique-orientated approaches to culture, rest upon such research. ${ }^{1}$ 


\section{The Institutional View}

Cultural studies is on the rise in the Portuguese academia. 2010 saw the launching of two doctoral programmes in this area: the programme jointly run by the Universities of Aveiro and Minho (two younger state universities located in the north), announced on the official web site as the 'first doctoral programme in cultural studies in Portugal'; and the programme offered by a private college, the Faculty of Human Sciences of the Portuguese Catholic University, based in Lisbon, in close association with the Centre for the Study of Culture and Communication (CECC), ${ }^{2}$ and as part of a vaster inter-institutional programme called 'the Lisbon Consortium'.

Both programmes fall in line with dominant international trends in cultural studies, bringing together research interests that are common to the humanities and the social sciences, especially around the topic of communication. This is especially clear in the first case, which combines a strong humanities component (ensured by the Department of Languages and Cultures of the University of Aveiro) with communication studies (ensured by the Communication and Society Research Centre, or CECS, of the University of Minho). Sociology, geography, history, philosophy, anthropology, psychology and heritage ('património') provide other interdisciplinary links. The programme presents itself as a response to the growing importance of culture in the job market - the cultural industries are mentioned - and promises to 'produce' professionals in the areas of: 'cultural creation, cultural promotion, cultural animation, cultural mediation and cultural dissemination'. The objective is to turn out professionals who are qualified to work in public libraries, book publishing, the production of information and cultural events, cultural associations, embassies, institutes, foundations, cultural centres, and the like. The programme also promises to equip students with the skills to work in multidisciplinary teams as problem-solvers in the areas of sustainable development; intercultural communication; business ethics; film and genre studies; media studies; internet studies; post-colonial studies; conservation, management and promotion of material and immaterial heritage; audience creation; cultural tourism; cultural marketing; cultural policies; biopower; biopolitics; human genomics; the 'anthropotechnological' imaginary, etc. Its problem-solving orientation is clearly stated: the future degree-holders are expected to be able to deal with problems concerning the populations and public powers (such as social discrimination; xenophobia; nationalisms; social tensions and low civic participation); the economic powers (for instance, through the creation of museums, festivals, events, tourist guide material and culture industries in general); and the various social groups who struggle for the recognition of alternative representations of themselves and the world or who demand that new socio-cultural practices be legitimated. One last objective is to encourage research on and critical engagement with these topics. Students have to take three obligatory courses - cultural studies 
theories and methodologies; intercultural communication; and sociology of culture - plus an optional course. ${ }^{3}$

Interdisciplinarity and cultural policy are also central to the idea of cultural studies endorsed by the CECC, at the Faculty of the Human Sciences of the Portuguese Catholic University. The main objective of this programme, as stated in the English brochure of the Lisbon Consortium, is 'to bring about the professional integration of students through advanced training in the multidisciplinary field of Cultural Studies based upon cooperation in academic reflection, scientific research, programming and cultural management'. ${ }^{4}$ Interdisciplinary 'interaction' across the fields of 'cultural studies, literary and artistic studies, performance studies, translation and media studies, cinema and history' is stressed. The master's programme offers the following courses: 'Culture, Art and Power'; 'Cognition and Creativity'; 'Performance Theory'; 'Cultural Entrepreneurship'; 'Visual Culture'; 'Culture and the Environment'; 'Globalization and Modern Culture'; and 'Writing Europe'. The doctoral programme shares two of these core courses (namely: 'Culture, Art and Power', and 'Performance Theory'), to which have been added five more: 'Cyberculture'; 'Visual Arts and Performance'; 'Literature and Modernity'; 'Issues in Cultural Studies and Film Studies'. ${ }^{5}$ In Portuguese, the names of these courses are slightly different, betraying greater proximity to literature and the 'study of culture'. ${ }^{6}$ The programme's relationship with cultural studies is rather ambiguous. Although the English brochure of the Lisbon Consortium uses the term 'cultural studies', the Portuguese brochure refers throughout to 'estudos de cultura' (rather than 'estudos culturais'). More importantly, the syllabi of most of the core courses make few references to the canonical works of cultural studies - this is particularly evident in 'Issues in Cultural Studies' ('Questões de Estudos de Cultura'), the key theoretical course, taught by a German lecturer and drawing essentially on German authors, which points to an understanding of culture that is more in line with the Kulturkritik tradition, in Francis Mulhern's terminology (2000). ${ }^{7}$

Like the University of Aveiro and the University of Minho (but from what seems to be a more status quo position), the Catholic University and the Lisbon Consortium are clear about their commitment to interact with the 'cultural economy', described, in their brochure, as a growing economic sector, responsible for 2.5\% of employment in Portugal. But if Aveiro and Minho adopt a more critical line of cultural studies - being closer to the four pillars proposed by Johan Fornäs, namely: culture, communication, contextualization and critique (Fornäs 1999: $132)^{8}$ - the programme of the Catholic University is weaker on either contextualization and critique, assuming more clearly an entrepreneurial job-orientated agenda. One of its major objectives is the 'professional integration of students', namely in cultural programming and management. Its incorporation in the Lisbon Consortium, alongside key elite institutions like the National Theatre Museum, the Portuguese Film Institute ('Cinemateca Portuguesa - Museu do Cinema'), the 
National Cultural Centre, the Calouste Gulbenkian Foundation, the Culturgest and the Lisbon Municipal Council, places it in a strong position to achieve this goal. ${ }^{9}$

Given the historical links of cultural studies to literature, one would expect to find a vibrant cultural studies scene in the humanities - especially in the context of English and American Studies. However, this is hardly the case - at least on an institutional level. The Faculties of Letters of the University of Porto and of the University of Lisbon offer very few graduate programmes in cultural studies, and these are to be found outside of their English departments. In the case of the former, the only post-graduate programme that could be linked to cultural studies is based in the Department of Portuguese and Romance Studies. Running since 2007, this is an M.A. in Literary and Cultural Studies and Inter-arts ('Mestrado em Estudos Literários e Culturais e Interartes'), a merging of previously separate M.A. programmes in literature. ${ }^{10}$ Its focus is still on literature, but it now offers the students a more flexible syllabus, in keeping with the Bologna convention that it professes to follow. The course is divided into two branches: 'Romance and Classical studies' ('Estudos Românicos e Clássicos'), with six variants ('Iberian cultures'; 'literary aesthetic'; 'French and Francophone studies'; 'Portuguese literature and literatures in Portuguese'; 'Classical literatures' and 'theory of literature'); and 'Comparative Studies and Intercultural Relations' ('Estudos Comparatistas e Relações Interculturais’), also with a focus on literature (namely, travelogues) and translation. The student will have a degree in one of the following scientific areas: literary criticism; cultural studies; cultural studies - classics; literature and comparative literature. ${ }^{11}$ Students can also proceed to the doctoral programme (in 'Romance Literatures and Cultures'), and they will specialise either in Romance literature or in cultural studies (i.e. 'estudos culturais'). As for the Department of Anglo-American Studies, its well-established M.A. programme in Anglo-American Studies has increased its range of optional courses, among which we can now find 'Cultural Studies' and 'Inter-art Studies and the Representation of Woman' (English in original). ${ }^{12}$ Its three areas of specialisation are: literature, culture and translation.

Similarly, the Department of English Studies of the Faculty of Letters of the University of Lisbon offers no specific programme in cultural studies. This absence appears the more striking if we consider that this was where recently-retired Professor Álvaro Pina, one of the greatest advocates of cultural studies in Portugal, used to work. ${ }^{13}$ Some of the courses currently included in the department's master's and doctoral programmes do draw on cultural studies theories and methodologies; however, the Centre for English Studies (CEAUL/ ULICES), the department's associated research centre, shows no clear commitment to pursuing systematic work in the field. This contrasts with the Centre for Comparative Studies (CEC), based in the same institution, where a strong interdisciplinary framework seems to have encouraged and facilitated the adoption of cultural studies approaches. This centre has three major research areas: (1) Intercultural Studies, 
dedicated to the study of travel literature, utopian texts, and translation; (2) 'Literary and Cultural European Studies', which pursues the study of Portuguese and Lusophone contexts vis-à-vis Europe; (3) 'Intersemiotic Studies', or 'Interart', concerned with the relations between literature, on one side, and film, theatre, painting, and architecture, on the other. ${ }^{14}$

Finally, the Faculty of Letters of the University of Coimbra - another bastion of classic humanities - evinces the same general trends. Following the recent Bologna-orientated reorganisation, in 2007, the new Department of Languages, Literatures and Cultures (which brings together people doing what used to be called 'Classical', 'Romance', 'Anglo-American' and 'Germanic' studies) offers, at an undergraduate level, a course called 'Introduction to Cultural Studies' ('Introdução aos Estudos Culturais') as an option for the different linguistic branches of the Modern Languages programme. ${ }^{15}$ It also offers an M.A. in Literary and Cultural Studies, which, despite the name, is closer to a comparative literature programme, being very much in line with the M.A. in English and American studies also run by this department. ${ }^{16}$

Generally speaking, all the master's and doctoral programmes offered by this Faculty seem to be centred on literature. Two recent developments, however, suggest that the situation may be changing: one is the M.A. and PhD in Feminist Studies - the only programme of the kind in Portugal, running since $2010 ;{ }^{17}$ the other is the doctoral programme, also launched in 2010, called 'Advanced Studies in the Materialities of Literature'. While both are still very much literatureorientated, the former is also described as 'interdepartmental', accepting students from all academic backgrounds, and the latter proposes to study literature vis-àvis the new technologies of communication and the other arts, stating as its ultimate goal to contribute to the 'renovation' of literary studies in Portugal in a manner that is 'already under way in the Anglo-American world and Northern Europe' and as part of 'the larger project of rethinking the Humanities in the era of new media'. Accordingly, the students are expected to develop, among other things, 'competences, skills, and research methods associated to the scientific domains of theory of literature, cultural studies, inter-art studies and other emerging fields' ${ }^{18}$

Outside of this account I have left the social sciences: history, sociology and anthropology, in particular, are having an active role in the current expansion of cultural studies (probably on a larger scale and with more far-reaching implications than the humanities). There is no doubt that many of the problems and themes that interest cultural studies cross over to these other disciplines and fields. Bibliographical references to cultural studies authors have become common in sociology and history (namely, in urban history and film history). For reasons that have been widely discussed, culture has been gaining ground, in the social sciences, as a research interest and many social sciences research centres now employ cultural studies researchers or work closely together with them. This is the case of the Centre for Social Studies (CES), chaired by sociologist Boaventura Sousa 
Santos, which has several projects in the area of cultural representation and maintains active collaborations with the Faculty of Letters of the University of Coimbra (the doctoral programme in Feminist Studies is one of them). This is also the case of the Centre for Research in Anthropology (CRIA), where I am based, which addresses culture as a subject and a problem in many of its projects, seminars and research lines, not least the one specifically dedicated to the study of cultural practices, politics and displays. ${ }^{19}$

\section{Underlying Problems and Tensions}

What seems to surface from the brief overview offered above - which is not and does not purport to be exhaustive - is that the on-going expansion of cultural studies in Portugal is greatly indebted to changes taking place at an institutional level. Two policy interventions have been of particular relevance: the implementation of the Bologna accords (which set in motion the so-called Bologna 'process') and the policies that have raised the economic profile of the cultural-turned-creative industries. The Bologna accords, signed in 1999, laid the foundations for the building of a common European Higher Education Area, encouraging interdisciplinary approaches and a more flexible curriculum. The document's aim - to allow students to customise their education and become more mobile within the European zone - has indirectly facilitated the engagement with cultural studies. Indeed, most of the new programmes discussed above acknowledge Bologna. ${ }^{20}$

The adoption of the creative industries policy model has likewise been responsible for this sudden institutional interest in cultural studies. This model, developed by Tony Blair's New Labour in the late 1990s to boost Britain's export trade, embodies the general shift to the 'new economy', which was largely dependent upon the expansion of the new information technologies (mostly software, computer games and electronic publishing) and the extraction of value from intellectual property rights (Miller \& Yúdice 2002; Garnham 2005; Ross 2009: 26). Incidentally, the model itself became one of Britain's most successful exports (Ross 2009: 20), officially arriving in Portugal during the 2005-2011 Socialist government led by José Sócrates. ${ }^{21}$ As a result, despite lack of empirical data (Miller 2004; Oakley 2004; Garnham 2005), the idea that culture holds the key to the country's economic problems enjoys now wide currency, even among cultural workers, who often turn to it in an attempt to defend the sector and secure their jobs. The much-trumpeted idea that there are great economic returns to be obtained from the cultural industries clearly informs (arguably, to a different extent) the doctoral programmes in cultural studies run by the Catholic University and by the Universities of Aveiro and Minho, making their engagement with more critical views less probable.

In this general favourable mood, it is hardly surprising to find that open academic confrontations over cultural studies have practically disappeared. An in- 
creasingly large number of students, lecturers and researchers are now claiming the label 'cultural studies' to describe their work and research interests. Work on or related to cultural studies is being carried out in different academic quarters from communication research centres (like the CECS, based in the University of Minho) to more classic literature centres (like the CEAUL/ ULICES and the CEC, based in the Faculty of Letters of the University of Lisbon, or the CETAPS, based in the Faculty of Letters of the University of Porto and the New Lisbon University). ${ }^{22}$ We can also expect to find cultural studies scholars (in a broader or narrower sense of the term) in more recently formed research centres with a deliberate focus on interdisciplinary work and the cultural/ creative industries (like the CECC, based in the Catholic University), or on the idea of 'inter-culture' (like the CEI, based in ISCAP, in Porto). ${ }^{23}$ The major research lines of all these centres overlap, differences being more of nuance and accent - to do with the centre's chief disciplinary affiliation, its institutional origins, contingent academic strategies, and the background and training of its main researchers - than with clearlystated theoretical or theory-driven projects. Further research would be needed to clarify each of these aspects.

Nevertheless, the label 'cultural studies' continues to be wrapped up in ambiguity, causing unease in certain quarters. As I have noted above, the brochure of the Lisbon Consortium adopts the term 'cultural studies' in its English version and 'estudos de cultura' (rather than 'estudos culturais') in its Portuguese version. Yet, in another English-speaking context - the 2011 meeting of the Portuguese Association for Anglo-American Studies (APEAA) - the option falls on 'studies of culture' ${ }^{24}$ These different wordings suggest the persistence of old tensions, which Álvaro Pina identified and wrote about in the late 1990s (incidentally, in response to a notice which appeared in an issue of the APEAA newsletter, disclaiming cultural studies). For Pina, cultural studies had to contend against 'the official knowledge in English and American studies' that, until April 1974, had been philologically-based - 'divorced from the present, blind to the quotidian and hostile to the contemporary' - and that, by the 1990s, was bound to a literary-studies paradigm, in which literature was first and foremost a 'field of distinction' (Pina 2000: 2 , 3). In such a context, 'cultural studies [was] not there, officially not, strategically not' (Pina 2000: 2), its only alternative being to exist as 'a place conquered in the space of the other' (Pina 2000: 4). Pina was then reflecting on the conditions of his own practice, as a teacher of English culture courses in a classic English department, but his words could, no doubt, find resonance in other cultural studies quarters.

The situation of cultural studies has, in the meantime, considerably changed. One of the effects of the market-turn in the academia has been the decline of the literary-studies paradigm - or, to put it more accurately, its redefinition to suit new market and governance aims. In many respects, and with no lack of irony, cultural studies has become something of a survival strategy to the humanities 
(and, to a lesser extent, the social sciences). The question, today, is not so much how to conquer 'a place in the space of the other' (as the 'other' now often bounces back to us in the guise of the self), but how to remain true to a cultural studies practice that is still interested in studying 'culture as such' (Pina 1999), in relation to its (and our) contexts, so as to tease out its precise meanings, usages and power alignments - in keeping with cultural studies' claims to a 'radical contextualization’ (Grossberg 2006: 7; Grossberg 2010: 30, 40).

One such context pertains to the national-international (or even transnational) articulations that underpin Portuguese cultural studies. For most of us, the notion that cultural studies arrived in Portugal in the 1990s, as part of a vaster international 'success story', begs little examination. This was when the ideas and theoretical frameworks that were shaping the debates on culture and power in the Anglo-American world were being made available (courtesy of so-called 'globalization') to Portuguese academics. As in other regions (namely, Scandinavia), cultural studies came in tow with the growing attention accorded to popular culture, youth culture and the media in the social sciences. Its presence was more controversial in the humanities, where cultural studies' trademark attack on the canon, together with its challenge of disciplinary boundaries, met with resistance, especially in more traditional quarters like literary studies (Sanches 1999; Silvestre 1999; Pina 2000). ${ }^{25}$

Indeed, the idea that 'estudos culturais' was an import from the Englishspeaking world dominates perceptions of the origins of cultural studies in Portugal. Although partly true - cultural studies is a 'travelling concept' (Bal 2000), owing its propagation to contact between academics and their work - this says little about the actual practices, meanings and conditions that have developed under its banner. As Pierre Bourdieu has pointed out, the transfer of ideas in an international context always entails a degree of 'structural disjuncture' (Bourdieu 1995/2000: 242), which is to say that there is always a gap between the projects (and terms) that are being compared. No new projects and terms develop in a vacuum, for their meanings can only be found in relation to existing 'local' projects and traditions, and their present forms and conditions. The point is not so much that the latter are 'home-grown', as opposed to 'imported' (even home-grown formations are influenced by external constellations), but that they are there, along with their own supporting and oppositional networks. These cannot be ignored or simply written off, lest we risk misrecognising the power relations and correlations that make up the field and misunderstand what is really going on, what is really at stake.

This, I believe, applies to Portuguese 'estudos culturais' - or cultural studies in Portugal - in which various national and transnational strands of cultural analysis and critique have converged. The kind of concerns associated with cultural studies had been troubling sectors of the Portuguese intelligentsia long before the 1990s. According to Álvaro Pina, '[c]ultural studies appeared on the Portuguese academ- 
ic scene in the first year after the April Revolution - from left Leavisite, Marxist and structuralist positions - as part of the struggle for an educated, participatory democracy' (Pina 1999: 2). The role that culture and cultural theory (or even 'metaculture') played in this struggle has been under-examined, but there is no doubt that they had a role to play, including outside the academia. The famous campaigns of civic and cultural action that the Movement of the Armed Forces (MFA) carried out between 1974 and 1975 testify to a deep political awareness of cultural issues (Almeida 2009), as do the numerous cultural groups and actions (spontaneous or politically-driven) that also appeared at the time and immediately afterwards. Further research on the theories and usages of culture is called for, namely to identify some of the 'intellectual spaces and practices of hope' (Pina 2003) that emerged at different historical moments (another example would be 'neo-realismo', which became influential in the 1940s - cf. Pina 2003).

In each of these moments the weight of national and transnational elements and its power implications are well worth looking into. As suggested above, apropos of the Lisbon Consortium brochures and the 2011 APEAA conference, the way the label 'cultural studies' is adopted or rejected according to different (national or international) contexts is an index of the different power strategies that cultural studies is capable of mobilising. On the one hand, there is symbolic capital to be gained from the international credentials of cultural studies, or even, in some quarters, from its reputation as an irreverent and marginal counter- or antidiscipline; on the other hand, these gains may come at the expense of a deeper and more direct involvement with local and national public debates. In the late 1990s, Álvaro Pina referred to the dilemma that a cultural studies scholar working in Portugal would often run into: to write a paper on a Portuguese topic and reduce one's chances of being accepted in an international cultural studies conference or to increase those chances by accommodating to a 'theme or a problematic which has become relevant in English-speaking countries' (Pina 2000). While this dilemma has become, to a certain extent, less acute - work on Portuguese cultural studies can now be presented and discussed on a rising number of national and international occasions and publications - the main problem remains, namely: how to produce work that is internationally relevant without failing our responsibilities as public intellectuals? In other words, how to combine our professional need to publish in English (which, among other things, requires that we fit in with an international/ Anglophone research agenda) and our desire to intervene as public intellectuals in the places where we live and work? Who should be our prime interlocutors? ${ }^{26}$

\section{By Way of Conclusion}

The present success story of cultural studies in Portugal has been largely built on an institutional level, being the result of top-bottom interventions more than overt 
intra-institutional conflicts. The shift to the 'new economy', which elevates culture to a key economic activity, has proved particularly efficacious in shaping a cultural studies agenda in Portugal. The cultural-turned-creative industries, we are told, are going to regenerate our cities, stimulate our production, increase the GDP, invert the balance of trade (increasing the exports through a shift from products to services), reverse the current budget deficit and so on and so forth. Last but not least, all of this is going to save the (somewhat resentful) humanities. In a context of high academic instability, where job scarcity and precariousness reign supreme, one cannot overestimate the pressures being currently put on academics and researchers to become increasingly more 'productive', seriously damaging their chances to commit to a more encompassing, truly interdisciplinary and socially-grounded intellectual project.

And yet such commitment is needed. Faced with an acute economic crisis and a programme of extensive public cuts (in line with the recent IMF-EU-ECB intervention), Portugal is now experiencing a moment of fast change and great intellectual confusion. More critical thinking is required, not less. Given its proven abilities to establish meaningful connections between apparently disconnected things, cultural studies is particularly well-placed to help us to make sense of the new culture-power alignments that are currently taking shape, of the present 'conjuncture' (Grossberg 2010), if we prefer, of which cultural studies is necessarily a part. And there is no shortage of research topics, concerning, for instance: (1) the new orthodoxies formed around the 'cultural industries' and the 'new economy' which, as a rule, exclude inquiries into the quality of work life in the creative industries (Ross 2009: 27), where precarious employment and deep income disparities are rampant (Miller \& Yúdice 2002); (2) the relationship between national and transnational cultural studies projects (or even between cultural studies and other intellectual movements); (3) the apparent conversion, in some academic quarters, of cultural studies into 'intercultural studies'. There is much to commend cultural studies for: ranging from its proven ability to mobilise literary critical analysis and reading skills (not only for meaning, but also for significance Grossberg 2010: 194) to its uncompromising commitment to complexity (Grossberg 2010: 16-17) and context. ${ }^{27}$ Having said that, there are also doubts concerning its 'transformative' politics, which (as everything else in this intellectual practice) cannot be taken for granted. What form will this transformative impetus take, considering the present moment of forced national 're-invention', in which much that has been thought 'solid' is rapidly 'melting into air'? How will these politics affect and be affected by other competing intellectual and political formations? Whether a cultural studies formation will prove useful in the current context or give way to other, more socially relevant, intellectual projects (possibly developing outside the academia) remains to be seen. In any event, the principled study of the relations between culture and power in Portugal, whatever the name it choses to adopt, will certainly depend on our ability - as academics, public intellectuals, 
activists or cultural studies practitioners - to understand the national, local and institutional conditions of our own practice.

\section{Acknowledgements}

This paper is an expanded version of a text presented at the Spotlight session 4 'South European Cultural Studies: The Mediterranean', as part of the Current Issues in European Cultural Studies Conference. I would like to thank Chantal Cornut-Gentille d'Arcy for her kind invitation to participate in this panel. I would also like to thank Maria João Ramos Silva for commenting on an earlier draft. The research presented here benefited from funding from the Portuguese Foundation for Science and Technology (FCT).

Sofia Sampaio is a Research Fellow at the Centre for Research in Anthropology (CRIA), in the Instituto Universitário de Lisboa (ISCTE-IUL), in Lisbon, Portugal. As part of her postdoctoral project, she is currently looking into the relationship between cinema and tourism. Her research combines methods and insights from film studies, history (including archival work) and anthropology. She is also interested in the geneology of intellectual movements and formations and their relation to national and transnational contexts. E-mail: psrss@iscte.pt

\section{Notes}

1 My assessment of the present situation of cultural studies in Portugal is far from comprehensive and acknowledges the need for further research. This would include, for instance, a systematic analysis of cultural studies publications (original and in translation), as well as interviews to some of its chief protagonists. I hope this paper may stimulate other reflexive engagements with past and present developments in the field.

2 The CECC ('Centro de Estudos de Comunicação e Cultura') is a research centre dedicated to the promotion and development, from a multidisciplinary perspective, of the study of culture, literature, translation, language and communication. Its key research interests are: the study of cultural creation in modernity, the inter-semiotic study of mediation (Luhmann, Kittler), the intercultural dialogue/conflict, and the study of translation, both as an inter-linguistic phenomenon and a process of cultural mediation and self-representation. It has three main research lines: 'Culture and Conflict'; 'Translating Europe across the Ages'; and 'Media, Technology, Contexts’. See

http://www.fch.lisboa.ucp.pt/site/custom/template/ucptpl_fac.asp?SSPAGEID=934\&lang=1 \&artigo=4479\&artigoID=4479 (accessed 19 May 2011).

3 For information on this programme, see: http://www.comunicacao.uminho.pt/ensino/content.asp?startAt=2\&categoryID=759\&newsID $=2034$ (accessed 14 May 2011). All translations from the Portuguese, unless otherwise stated, are my own.

4 See p. 4 of the Lisbon Consortium brochure: 
http://www.fch.lisboa.ucp.pt/resources/Documentos/brochuras_cursos/FCH_Consortium_bro chura_FEV11.pdf (accessed 18 May 2011)

5 Lisbon Consortium Brochure, p. 4, at: http://www.fch.lisboa.ucp.pt/resources/Documentos/brochuras_cursos/FCH_Consortium_bro chura_FEV11.pdf (accessed 18 May 2011)

$6 \quad$ In Portuguese, 'Globalization and Modern Culture’ becomes ‘Tradução e Globalização’ (i.e. 'translation and globalization'), whereas 'Issues in Cultural Studies’ is rendered as ‘Questões de Estudos de Cultura'. See:

http://www.fch.lisboa.ucp.pt/site/custom/template/ucptpl_fac.asp?SSPAGEID=924\&lang=1 \&artigo=4497\&artigoID=4498 (accessed 18 May 2011). For the syllabus and reading lists see also:

http://www.fch.lisboa.ucp.pt/site/custom/template/ucptpl_fac.asp?SSPAGEID=926\&lang=1 \&artigo=4566\&artigoID=4567 (accessed 18 May 2011).

7 For the syllabus of this course, see: http://www.fch.lisboa.ucp.pt/resources/Documentos/programas_doutoramentos/DEC_Questo esEstudosCultura.pdf (accessed 23/05/2011). References to cultural studies works do appear in the syllabi of one of the core courses ('Cultura, Arte e Poder') and in some of the optional courses (such as 'Television Studies' and 'Creative Industries: Theory and Practice’).

8 This is clear in Maria Manuel Baptista’s text on cultural studies (Baptista 2009). The author is the director of the Aveiro and Minho doctoral programme.

9 The National Cultural Centre is a cultural society founded in 1945; the Calouste Gulbenkian Foundation is the longest-running private Foundation in Portugal (it is also one of the most active, especially in the arts). Finally, the Culturgest is the cultural branch of Portugal's major bank - still state-owned at the time of writing, but probably not for long.

10 Namely, 'Mestrados em Literatura e Cultura Comparadas, Literatura Portuguesa Moderna e Contemporânea e Teoria da Literatura / Cursos Integrados de Estudos Pós-Graduados em Culturas Ibéricas e em Literaturas Românicas'. See this Faculty’s report on the Bologna process, or 'Relatório da concretização do processo de Bolonha, anos lectivos de 2006/2007 e 2007/2008', Faculdade de Letras da Universidade do Porto, p. 12, at: http://sigarra.up.pt/flup/web_gessi_docs.download_file?p_name=F12785065/Relatorio_Bolo nha_FLUP20092.pdf (accessed 13 May 2011).

11 For more information, see: http://sigarra.up.pt/flup/cursos_geral.FormView?P_CUR_SIGLA=MELCI (accessed 13 May 2011).

12 See http://sigarra.up.pt/flup/noticias_geral.ver_noticia?P_NR=2822 (accessed 14 May 2011). I could not access the syllabi of these courses.

13 Álvaro Pina and the group of graduate students that met under the Culture and Society graduate programme were active in the foundation of the Iberian Association of Cultural Studies (IBACS), which formally took place in 2001, at the University of Alcalá de Henares. Between 2002 and 2005, the group was also involved in the organisation of the three editions of the Language, Communication and Culture international conferences, as well as the 9th International Culture and Power Conference, one of the largest cultural studies conferences ever organised in Portugal, which was hosted by the Faculty of Letters of the University of Lisbon, in November 2003. This conference had four international keynote speakers - Chantal Cornut-Gentille d'Arcy (University of Zaragoza), Handel K. Wright (University of British Columbia), Mica Nava (University of East London), and Lawrence Grossberg (University of North Carolina at Chapel Hill) - and circa 130 papers. For further information, including announcements and the programme, see: http://mundiconvenius.pt/2003/cultural/ (accessed 19/05/2011). The Portuguese participation in the IBACS is, to my knowledge, currently very low. On the failure of the 'Iberian project', see Cornut-Gentille D’Arcy (2009). 

In reflection about cultural studies in France, Anne Chalard-Fillaudeau has also acknow edged the impact of Bologna in the field (2009: 834; 847). For a more critical take on this issue, linking Bologna to the educational needs of global capitalism, see Allaine Cerwonka's discussion of cultural studies in the former state socialist countries of Central and Eastern Europe and the former Soviet Union (2009: 727-729).

21 In Portugal, the two landmark policy-driven documents on the creative industries are The Economy of Culture in Europe, a study prepared by the KEA for the European Commission (2006), as part of the Lisbon 2000 agenda, and the report on the 'cultural and creative sector', prepared by Augusto Mateus \& Associados (2010) for the then Minister of Culture, Gabriela Canavilhas (cf. Silva 2012: 61-63).

22 CETAPS is the acronym for Centre for English, Translation and Anglo-Portuguese Studies.

23 The Centre for Intercultural Studies (CEI) is based in the Institute of Accounting and Administration of Porto (ISCAP), a public institution that is part of the Polytechnic Institute of Porto. For the kind of work it promotes, see the programme of the II International Conference on Intercultural Studies (ISCAP, 25 - 27 May 2011), at:

http://www.iscap.ipp.pt/ cei/II_Congresso.html (accessed 17 May 2011). The conference was strong in papers on intercultural representation (especially in literature and cinema). It also included panels in comparative law across cultures, intercultural communication, translation studies, cultural tourism, travelogues and gender studies. The large paper turnout suggests that these topics are extremely popular at present.

24 'Studies of culture' (English in original), defined in the call for papers as a 'general area', was the name of the panel organised by the CECC, which attracted the kind of work normally associated with cultural studies. The meeting was entitled 'Current Debates in English and American Studies' and took place in 12-14 May 2011, at the Faculty of Arts and Humanities of the University of Coimbra. For the programme, see:

http://www.apeaa.uevora.pt/Final_Program_32APEAA_3.5.pdf (accessed 17 May 2011). For the call for papers, see http://www.apeaa.uevora.pt/ (accessed 17/05/2011). For another example of how terminology matters and is an object of negotiation in national contexts, see Chalard-Fillaudeau (2009).

25 Interdisciplinary academic practices proved crucial for the elaboration of some of these critiques. Sanches' article, for instance, was built from within German studies, but published in Etnográfica, one of the major Portuguese anthropological journals.

26 Mikko Lehtonen also raised this problem at the Current Issues in European Cultural Studies Conference.

27 This understanding of cultural studies (as requiring reading skills, the acknowledgment of complexity and the examination of context) has been guiding my practice, even when dealing 
with literary texts, which - following Lawrence Grossberg's theoretical proposal (2010: 26; 66; 203) - I take to be an entrance point into a specific conjuncture rather than the object of my research. Hence, more than an exercise in literary criticism, my take on E.M. Forster's Italian novels (Sampaio 2012) aims ultimately at describing the specific conjuncture that assembled certain tourist practices and the political and literary culture of liberalism in Edwardian England, the main elements of which continue to be active in our days.

\section{References}

Almeida, Sónia Vespeira de (2009): Camponeses, Cultura e Revolução: Campanhas de Dinamização Cultural e Acção Cívica do M.F.A. (1974-1975), Lisboa: Edições Colibri and IELT.

Bal, Mieke (2000): 'Crossroads Theory and Travelling Concepts: From Cultural Studies to Cultural Analysis’, Jan Baetens \& José Lambert (eds): The Futures of Cultural Studies: Essays in Honour of Joris Vlasselaers, Leuven: Leuven University Press, 3-21.

Baptista, Maria Manuel (2009): 'Estudos Culturais: O quê e o como da Investigação’, Carnets, Cultures littéraires: nouvelles performances et développement, no. spécial, automne / hiver, 451-461: http://revistas.ua.pt/index.php/Carnets/article/view/466/422 (accessed 20 September 2012).

Bourdieu, Pierre (1995/2000): 'Passport to Duke', Loïc Wacquant (trans), Nicholas Brown and Imre Szeman (eds): Pierre Bourdieu: Fieldwork in Culture, Lanham, MD/ Boulder/ New York/ Oxford: Rowman \& Littlefield, 241-46.

Chalard-Fillaudeau, Anne (2009): 'From Cultural Studies to Études Culturelles, Études de la Culture, and Sciences de la Culture in France', Cultural Studies, 23:5-6, 831-854.

Cerwonka, Allaine (2009): 'Higher Education "Reform”, Hegemony, and Neo-Cold War Ideology’, Cultural Studies, 23:5-6, 720-735.

Cornut-Gentille D’Arcy, Chantal (2009): ‘”A Room of One’s Own”? Cultural Studies’ Relationship to Institutionalization and Disciplinarity in Spain', Cultural Studies, 23:5-6, 855-872.

Fornäs, Johan (1999): 'Advancing Cultural Studies in Sweden: The ACSIS proposal', Statement for the international workshop 'Advancing Cultural Studies' at Södergarn Conference Centre, Lidingö near Stockholm, 4-4 February, 123-158: http://www.isak.liu.se/acsis/publikasjoner/1.91935/acsreport1999.pdf (accessed 20 September 2012).

Garnham, Nicholas (2005): 'From Cultural to Creative Industries: An Analysis of the Implications of the "Creative Industries" Approach to Arts and Media Policy Making in the United Kingdom', International Journal of Cultural Policy, 11:1, 15-29.

Grossberg, Lawrence (2006): 'Does Cultural Studies have Futures? (Or What's the Matter with New York?): Cultural Studies, Contexts and Conjunctures’, Cultural Studies, 20:1, 1-32.

------ (2010): Cultural Studies in the Future Tense, Durham and London: Duke University Press.

KEA, European Affairs (2006): The Economy of Culture in Europe, Study Prepared for the European Commission (Directorate-General for Education and Culture): http://www.keanet.eu/ecoculture/studynew.pdf (accessed 20 September 2012).

Mateus, Augusto \& Associados (2010): O Sector Cultural e Criativo em Portugal - Relatório Final, Estudo para o Ministério da Cultura (Gabinete de Planeamento, Estratégia, Avaliação e Relações Internacionais): http://www.mincultura.gov.pt/SiteCollectionDocuments/Imprensa/SCC.pdf (accessed 20 September 2012).

Miller, Toby (2004): 'A View from a Fossil: The New Economy, Creativity and Consumption Two or Three Things I don’t Believe in', International Journal of Cultural Studies, 7:1, 55-65. Miller, Toby \& George Yúdice (2002): Cultural Policy, London/ Thousand Oaks: Sage. 
Mulhern, Francis (2000): Culture/ Metaculture, London and New York: Routledge.

Oakley, Kate (2004): 'Not so Cool Britannia: The Role of the Creative Industries in Economic Development', International Journal of Cultural Studies, 7:1, 67-77.

Pina, Álvaro (1999): 'Making Contexts Visible', Cultstud-L: http://www.cas.usf.edu/communication/rodman/cultstud/columns/ap-08-08-99.html (no longer accessible).

----- (2000): 'Teaching and Doing Cultural Studies in Portugal', Cultstud-L: http://www.cas.usf.edu/communication/rodman/cultstud/columns/ap-30-01-00.html (no longer accessible).

------ (2003): 'Intellectual Spaces of Practice and Hope: Power and Culture in Portugal from the 1940s to the Present', Cultural Studies, 17:6, 751-766.

Ribeiro Sanches, Manuela (1999): 'Nas Margens: Os Estudos Culturais e o Assalto às Fronteiras Académicas e Disciplinares’, Etnográfica, III:1, 193-21: http://ceas.iscte.pt/etnografica/docs/vol_03/N1/Vol_iii_N1_193-210.pdf (accessed 14 May2011).

Ross, Andrew (2009): Nice Work if you can get it: Life and Labor in Precarious Times, New York and London: New York University Press.

Sampaio, Sofia (2012): “I Wish Something Would Happen to You, My Friend!” Tourism and Liberalism in E.M. Forster's Italian Novels’, Textual Practice, 26:5, 895-920.

Silva, Maria João Ramos da (2012): Mason \& Barry e a Construção da Mina De São Domingos: Indústria, Turismo, Globalização, Lisboa: Faculdade de Letras da Universidade de Lisboa (unpublished PhD Thesis).

Silvestre, Osvaldo (1999): 'Caminhos Que Se Bifurcam: Estudos Literários Ou Estudos Culturais?’, Ciberkiosk: http://www.uc.pt/ciberkiosk (no longer available). 